Лариса Ющишина, кандидат економічних наук, доцент, Східносвропейський національний університет імені Лесі Українки, кафедра економіки, безпеки та інноваційної діяльності підприємства, м.Луцьк; ORCID ID: 0000-0001-8926-7577 e-mail: yushchyshyna.larysa@ eenu.edu.ua

Вікторія Пиль, здобувачка вищої освіти, Східносвропейський національний університет імені Лесі Українки, кафедра економіки, безпеки та інноваційної діяльності підприємства, м.Луцьк; ORCID ID: 0000-0002-5003-4554, e-mail: nikavika24082001@ukr.net

https://doi.org/10.29038/2411-4014-2020-02-121-129

\title{
ЕННЕАГРАМА В БІЗНЕСІ: НОВИЙ ІНСТРУМЕНТ УПРАВЛІННЯ КОМУНІКАТИВНИМИ ПРОЦЕСАМИ В КОНФЛІКТІ
}

У статті розглянуто сутність еннеаграми як докладної карти особистості - іï сильні та слабкі боки, потреби, побоювання і можливості. Викладено сучасні концепції формування та основні методологічні підходи до використання еннеаграми. Охарактеризовано дев'ять еннеатипів та виокремлено чотири основних рівні використання еннеаграми сучасними бізнес-організаціями. Визначено цінність еннеаграми, що полягає у можливості змінити на краще динаміку конфлікту завдяки баченню індивідуальності кожного працівника. Виокремлено особливості впливу еннеатипу на поведінку різних категорій персоналу організації. Доведено можливість застосування еннеаграми як інструменту для управління комунікативними процесами в конфлікті.

Ключові слова: еннеаграма, конфлікт, комунікативний процес, управління, бізнес.

Лариса Ющишина, кандидат экономических наук, доцент, Восточноевропейский национальный университет имени Леси Украинки, кафедра экономики, безопасности и инновационной деятельности предприятия, г. Луцк

Виктория Пыль, соискательница высшего образования, Восточноевропейский национальный университет имени Леси Украинки, факультета экономики и управления, г. Луцк

\section{ЭННЕАГРАММА В БИЗНЕСЕ: НОВЫЙ ИНСТРУМЕНТ УПРАВЛЕНИЯ КОММУНИКАТИВНЫМИ ПРОЦЕССАМИ В КОНФЛИКТЕ}

В статье рассмотрена сущность эннеаграммы как подробной карты личности - ее сильные и слабые стороны, потребности, опасения и возможности. Изложены современные концепции формирования и основные методологические подходы к использованию эннеаграммы. Охарактеризованы девять эннеатипов и выделены четыре основных уровня использования эннеаграммы современными бизнес-организациями. Определены ценность эннеаграммы, которая заключается в возможности изменить к лучшему динамику конфликта благодаря лицезрению индивидуальности каждого сотрудника. Выделены особенности влияния эннеатипа на поведение персонала организации различной категории. Доказана возможность применения эннеаграммы как инструмента для управления коммуникативными процессами в конфликте.

Ключевые слова: еннеаграмма, конфликт, коммуникативный процесс, управление, бизнес.

Larysa Yushchyshyna, Ph.D. in Economics, Associate Professor, 
Lesya Ukrainka Eastern European National University, Department of Economics, Security and Innovation of Enterprise,

Lutsk

Viktoriia Pyl, Student,

Lesya Ukrainka Eastern European National University, Department of Economy and Management,

Lutsk

\section{ENNEAGRAM IN BUSINESS: A NEW TOOL FOR MANAGING COMMUNICATION PROCESSES IN CONFLICT}

Introduction. Modernity shows that the most important factor in ensuring business competitiveness is its organizational culture. Conflicts cause significant damage to maintaining the team atmosphere in good condition, effective interaction in groups and cause loss of production resources and time. Modern managers must have a communicative technique for solving conflict situations with all their consequences without negatively affecting the organizational culture of the enterprise. The need to find new sources of managing communication processes in a conflict is extremely relevant and absolutely indisputable today. Enneagram is the key that will help to find an approach to each person and prevent the conflict from developing.

The purpose of the article. Demonstrate enneagram as a tool for managing communication processes in conflict.

Results. The essence of the enneagram as a detailed personality map - its strengths and weaknesses, needs, concerns and opportunities. Modern concepts of formation and basic methodological approaches to the use of the enneagram are described. Nine enneatypes are described and four main levels of using the enneagram by modern business organizations are highlighted. The value of the enneagram, which is the possibility to change the conflict dynamics for the better thanks to the vision of each employee's individuality, is determined. The features of the impact of the enneagram on the behavior of different categories of personnel in the organization are highlighted.

Conclusions. Different types of management decisions require different information data. The Enneagram can become an effective tool for a manager in making managerial decisions, which, in turn, will increase business efficiency. The most important advantages of the enneagram are awareness of other people's peculiarities and the possibility to find a personal approach, to reveal the employee's potential, to motivate him/her correctly and to solve conflicts at early stages. Therefore, modern business organizations should pay more attention to the possibility of using enneagram as a tool for analysis and management of communication processes in a conflict to create a favorable atmosphere in the team, increase productivity and develop optimal solutions for complex conflict and crisis situations.

Keywords: enneagram, conflict, communication process, management, business.

Постановка проблеми та іï значення. Наразі підприємства функціонують у складних соціально-економічних умовах. Міжособистністні конфлікти, грубість призводять до відчуження, протистояння, опору нововведенням, обертаються моральними втратами (боягузтво, лицемірство, підлабузництво). Сучасність показує, що найважливішим фактором гарантування конкурентоспроможності бізнесу є його організаційна культура. Конфлікти завдають значної шкоди підтриманню атмосфери колективу в хорошому стані, ефективній взаємодії у групах та стають причиною втрат виробничих ресурсів і часу. Нерідко конфлікти призводить до фізіологічних втрат: нервових зривів, стресів, серцевих та інших захворювань. Сучасний керівників має володіти комунікативною технікою вирішення конфліктних ситуацій з усіма їх наслідками без негативного впливу на організаційну культуру та здоров'я працівників. Надзвичайно актуальним і абсолютно безспірним $\epsilon$ те, що потрібно шукати нові джерела управління комунікативними процесами в конфлікті, і знаходитися вони можуть у системній моделі еннеаграми особистості.

На даний час не існує єдиної точки зору вчених на визначення шаблону єдиної правильної поведінки при вирішенні конфліктів, проте еннеаграма виступає ключем, що допоможе знайти підхід до кожної людини та не допустити розвитку конфлікту. Незважаючи на своє прадавнє коріння, еннеаграма набуває наукового підтвердження у сучасних дослідженнях та активно й успішно використовується за рубежем.

Аналіз останніх досліджень і публікацій. В силу специфіки змісту, розвитку та поширення еннеаграми в Україні - вітчизняні напрацювання за темою дослідження практично відсутні і наше 
дослідження опирається в основному на зарубіжні та перекладні джерела. Основні методологічні тенденції виявляємо саме в зарубіжній літературі у найбільш відомих працях дослідників усіляких напрямів, таких як К. Наранхо, Д. Рісо, Р. Хадсон, Р. Теллон, М. Сікора, Л. Кінгма, Дж. Лепід-Богда, К. Бергхоф, М. Бэлл, А. Панграцці, Х. Макані та ін.

Цікавий підхід до використання моделі еннеаграми подано у праці Клаудіо Наранхо, де автор презентує iї в якості інструменту підвищення особистих знань та здолання обмежень, які накладає на сучасну людину іiі невроз і характер [1]. Мітчел Паква, навпаки, висловлює жорстку критику до індустрії еннеаграми, знаходячи в ній окультне коріння і соціально-психологічні зловживання [2].

За кордоном широке розповсюдження отримала методика, побудована на еннеаграмі, що графічно відображає співвідношення між різними типами особистості стосовно їх поведінки в робочій обстановці. На думку Хелени Макані, еннеаграма $\epsilon$ не лише корисним інструментом для особистісного розвитку, але й дозволяє значно покращити комунікацію з іншими людьми [3]. Слід згадати інноваційну за своїм підходом працю Р.Теллона та М. Сікори [4], яка є не чим іншим, як картою для досягнення високих результатів та успіху в будь-якій професійній діяльності.

Глибокі дослідження еннеаграми стосовно підсвідомого конфлікту на робочому місці проведені Лі Кінгма. У своїй праці [5] Л. Кінгма на основі особистісного досвіду та багаторічного спостереження доводить, що основні еннеатипи, які перебувають у взаємодії між собою, тим самим дають корисні рішення для конфліктів. Авторка розглядає конфлікт як звичайне явище, і заявляє про можливість підвищення майстерності вирішення конфліктів на основі знань типів еннеограми.

Інтерес представляють також індикатор типу особистості за еннеаграмою Д. Рісо і Р. Хадсона (RHETI), що включає 144 питання для розуміння системи вивчення еннеатипів (зауважимо, що через проблеми з науковою обгрунтованістю теоретичної бази та валідалізацією тестів індикатор поки що не взятий науковим співтовариством на озброєння) [6], опитувальник Томаса-Кіллмена (KTI), щодо стратегій поведінки при конфлікті [7] та тренінг-курс Анни Протасової, мінського майстера еннеаграми, щодо використання еннеаграми при конфліктах в бізнесі [8]. Проте, відсутність достатньої наукової бази вивчення еннеограми 3 ціллю практичного застосування бізнесорганізаціями потребує подальших досліджень.

Мета i завдання статті. Продемонструвати еннеаграму як інструмент управління комунікативними процесами в конфлікті.

Виклад основного матеріалу. В Україні, соціально-психологічної методи набувають все більшого поширення. Вони дозволяють відкрити організаційний потенціал, призначати потрібних кандидатів на керівні посади, надають допомогу керівникам при вирішені конфліктів без появи негативних наслідків для корпоративної культури організації [9, с. 291].

Еннеаграма - це психологічний інструмент, який може бути корисний у різних сферах життя, в тому числі й у бізнесі. Окремі компанії застосовують ऑï для підвищення продуктивності праці працівників, підбору персоналу і тімбілдінгу.

Термін «еннеаграма» у перекладі 3 грецької означає «9 фігур», адже в основі лежить фігура 3 дев'ятьма точками (рис 1). Точки розміщуються за колом і кожна з них відповідає тому чи іншому типу особистості. Всі типи взаємопов'язані, хоч і $є$ унікальними, але разом утворюють єдине ціле [10].

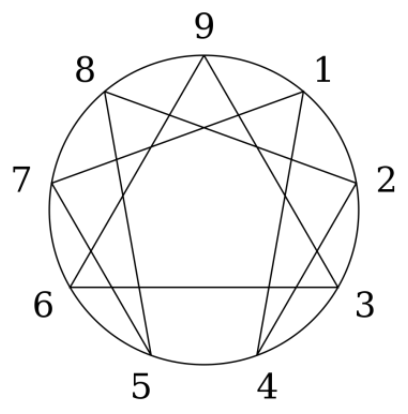

Рис 1. Загальний вигляд фігури еннеаграми Джерело : [10]. 
Зображення еннеаграми можна виявити у давньогрецьких математиків, в ранніх християнських і перських традиціях. Західний світ познайомився з еннеаграмою в XX столітті завдяки філософу Г. Гурджиєву. У 60-і роки філософ О. Ічазо спільно з психіатром К. Наранхо дали еннеаграмі друге народження - доповнили філософські ідеї Гурджиєва напрацюваннями реальної психології. Згодом на основі еннеаграми вони розвивали універсальну психологічну концепцію. У сучасному вигляді вона включає в себе розробки багатьох психологічних шкіл і підходів і співвідноситься з класичної психоаналітичної діагностикою [11].

М. Паква не погоджується, що еннеаграма це логічна конструкція, яку потрібно вивчати: «На даний момент я не відчуваю повагу до індустрії еннеаграмми. Слід поставити під сумнів і піддати дослідженню існування саме дев' яти типів особистості. Число дев'ять було заздалегідь продиктовано Ічазо і Наранхо структурою окультної фігури еннеаграми. На яких психологічних даних грунтується твердження про існування лише дев'яти основних типів?» [2].

Логічно, що всіх людей не можна віднести лише до 9 типів, адже є ряд факторів (крила, підтипи, рівні розвитку), що впливають на поведінку індивіда, і як результат існує 486 можливих варіантів типів. Розглянемо більш детально, як утворилося дане число. Мітчель Паква не дослідив (не врахував) той факт, що у кожного типу є 2 крила, в які він переходить залежно від життєвих ситуацій (відповідно 9 типів*2=18), окрім типів $є$ три підтипи: безпечний, соціальний та парний, що також впливає на поведінку та цінності індивіда $(18 * 3=54$ варіанти) і не менш важливе - рівні розвитку, їх $є 9$ (54*9=486 варіацій типів). Д. Рисо та Р. Хадсон розділили їх на три види: здоровий, середній та нездоровий [10]. За дослідженнями А. Протасової, на здорових рівнях розвитку, 3 першого до третього, знаходяться всього 1-2\% людей, що перебувають у гармонії між своїм тілом і розумом [8]. Звичайна людина здатна досягнути третього рівня шляхом позбавлення від патернів та глибокого пропрацювання духовного розвитку, що є досить складним процесом і на це йдуть роки. На середніх рівнях розвитку, від четвертого до шостого, знаходяться 94-95\% населення [8], що також цілком нормально, адже нами керує заздрість, використовуються маніпуляції тощо. Нездорові рівні найнебезпечніші, до них відноситься сьомий, восьмий та дев'ятий рівень. Люди, що опинилися або знаходяться на цих рівнях не можуть самостійно піднятися на середній рівень, їм потрібна допомога психолога/психіатра, залежно від ситуації. Дані люди бачать світ з іншого боку - через призму злості та несправедливості. Зазвичай на нездорових рівнях опиняються самогубці, наркомани, вбивці, люди 3 алкогольною залежністю тощо. Важливо не плутати рівні розвитку з типами особистості. Рівень розвитку насамперед залежить від умов, в яких виросла особа, формувалася психіка та модель поведінки. Досить високий відсоток перебування людей на середніх рівнях розвитку пояснюється використанням застарілих методів виховання в середньостатистичних сім'ях. 3 типами еннеаграми не так. Людина народжується з одним типом, який протягом життя не змінюється, а розвиток особистості відбувається виключно завдяки підніманню рівнями розвитку вверх.

Беручи ці всі фактори до купи, розуміємо що еннеаграма це не просто дев'ять необгрунтованих чисел. Існують і будильники, i червоні прапори для кожного типу, що виступають своєрідними сигналами про перехід типу на середні та нездорові рівні.

Як зазначають I. Адізес, І. Маданес, на відміну від більшості поширених підходів до бізнескоучингу енеаграма $є$ докладною картою особистості - ii сильні і слабкі сторони, потреби, побоювання і можливості. Крім того, завдяки енеаграмі можна багато чого довідатися про те, як ми схильні реагувати на події під впливом різних життєвих обставин. Аналіз особистості за енеаграмою Адізеса включає:

1) визначення енеатипу особистості;

2) дослідження специфічної сторони інтелекту відповідно до пов'язаного типу [12].

Еннеаграма часто використовується психологами, а уже з 2019 року набуває стрімкої популярносі серед населення та починає впроваджуватися у бізнес-організації як новий інструмент управління.

Проведені дослідження дозволили виокремити чотири основних рівні, на яких сучасні бізнесорганізації використовують еннеаграму:

1. Індивідуальний (формування свідомості працівника). Використовується при відборі кандидатів, адже певні типи схильні до виконання різних видів робіт. 
2. Міжособистісний (покращення міжособистісного спілкування). Компанії організовують тренінги, що зі сторони еннеаграми позитивно впливає на розвиток співробітників та допомагає при визначні їх сильних чи слабких рис характеру.

3. Груповий (створення ефективного колективу, вирішення конфліктів). На цьому рівні еннеаграма вкорінюється безпосередньо в колектив та елементарні знання щодо відмінності типів підвищують свідомість кожного працівника та дозволяє неупереджено ставитися до міжособистісних відмінностей.

4. Організаційний (формування корпоративної культури). Еннеаграма на четвертому рівні використовується як ключ до підбору ефективної системи мотивації, що максимально розкриє продуктивність праці кожного типу.

Тип особистості - це основний, рушійний мотив людини, що формується в дитинстві і не змінюється протягом життя. Представникам кожного типу притаманний унікальний набір психологічних механізмів і характеристик, які на несвідомому рівні впливають на те, як люди сприймають світ, на їх образ думок і переживань, i, в кінцевому підсумку, на їх поведінку в колективі. Дамо характеристику основних типів еннеаграми.

Тип 1 - Перфекціоніст: раціональні, ідеалістичні, проникливі, цілеспрямовані, володіють сильним самоконтролем. Головний страх - бути поганим, злим, неідеальним. Гнів відбувається у вигляді критики, саркастичних зауважень, повчань в різкій формі.

Тип 2 - Помічник: дбайливий, люблячий тип еннеаграми. Метою свого життя вони вибирають турботу про близьких і отримання подяки за цю турботу.

Тип 3 - Досягатор: основний страх - бути нікчемними, не мати цінності крім своїх досягнень. Найуспішніші, видатні люди, добре мотивують своїм прикладом, енергією. Трійок називають хамелеонами, вони легко пристосовуються і адаптуються до різних ситуацій. Вимикають емоції, тому що вважають їх перешкодою продуктивності та успішності.

Тип 4 - Індивідуаліст: найкреативніший, наповненний творчістю, емоційно виразний i драматизуючий тип, дуже темпераментний. Основний страх - не мати індивідуальності.

Тип 5 - Спостерігач: інтелектуальні, проникливі, інноваційні глибокі. Основний страх - бути безпорадним, некомпетентним. Постійно обмірковують і аналізують.

Тип 6 - Лояліст: відданий, орієнтований на безпеку тип. Базовий страх - залишитися без підтримки. Скептичні у відношенні до всього нового і невідомого. Люблять, коли все чітко і за правилами.

Тип 7 - Ентузіаст: генератори ідей, шукачі пригод, спонтанні, місцями розсіяні, швидко приймають рішення. Практичні, залучені в безліч проектів, зазвичай перестрибують із однієї теми на іншу.

Тип 8 - Бос: сильний, домінуючий, рішучий тип, що ранимий всередині. Основна боязнь контроль і порушення кордонів. Борються з труднощами, мотивують на боротьбу оточуючих, мають здатність переконувати людей.

Тип 9 - Миротворець: чутливі та уперті. Найголовніше у житті: спокій і гармонійні відносини 3 людьми [10].

На думку Р. Арзуманова, «найефективніша група - це та, в складі якої знаходяться люди 3 несхожими рисами характеру, чиї погляди сприяють досягненню цілей організації і створенню корпоративного духу, де маючи високий статус члени групи не домінують» [13, с.58]. А. Панграцці вбачає, що більшість людей є екстравертами і вони, будучи в групі, черпають свою енергію від інших людей [14].

На нашу думку, для розв'язку конфліктних ситуацій слід використовувати гармонійні групи. Виокремлюють три таких види:

1. Група компетентного підходу (типи $1 ; 3 ; 5)$.

2. Група позитивного сприйняття (типи $2 ; 79$ ).

3. Експресивна група (типи 4; 6; 8) [15].

Гармонійні групи вказують на те, як ми справляємося 3 конфліктами та труднощами, наші дії при неотриманні бажаного. Розкривають фундаментальний спосіб захисту нашої особистості від втрат та розчарувань. 
1. Група компетентного підходу: основна причина конфліктів типів $1 ; 3 ; 5$ - система, або $є$ iї відсутність. Дані типи навчилися справлятися з трудностями, відкладають в сторону свої особисті почуття, стараються бути об'єктивними, ефективними та компетентними. Вирішують проблеми логічно і очікують, що інші чинитимуть так само. Зазвичай, власні потреби та почуття-залишають на задньому плані.

2. Група позитивного сприйняття: основна причина конфліктів типів 2; 7;9 - потреби. Дані типи реагують на конфлікти та трудності через призму «позитиву», оптимістично дивляться на речі, проте важко сприймають неприємні життєві ситуації. У них відсутній баланс між своїми потребами і потребами оточуючих. У двійок,стратегія розв'язку конфлікту - придушення власних потреб,емоцій розчарування та злості. У дев'ятого типу - відкладання проблем на потім.

3. Експресивна група: основна причина конфліктів типів 4; 6; 8 - відносини з людьми. Дані типи емоційно реагують на конфлікти та проблеми, спочатку говорять, а потім думають. Переконані, що інші мають відповідати їх емоціональному стану. Не вміють довіряти.

Першоджерелом конфлікту або умовою його виникнення вважається конфліктна ситуація, що призводить до загострення стосунків між конфліктуючими сторонами. Тому ми вивчили конфліктні ситуації для різних типів еннеаграми. Результати були такі:

1) перший тип (перфекціоніст) вибухає, коли колеги порушують правила, не прибирають робочі місця, не слідують встановленій процедурі виконання завдань, не беруть відповідальність за свої помилки, натомість придумують виправдання;

2) другий тип (помічник) дратується, коли колеги здійснюють необдумані вчинки, безпідставно критикують, ставлять свої інтереси вище інших, керівник відноситься до співробітників без поваги;

3) для третього типу (мотиватора, досягатора) конфліктною є ситуація, коли колеги не вкладаються в дедлайни, витрачають час, приписують собі досягнення інших, перешкоджають досягненню цілей, зустрічі, що не принесли результат;

4) для четвертого типу (індивідуаліста) - колеги не цінують їхні результати, фокусуються на швидкості виконання, замість естетики, виконувати завдання без перспективи розвитку;

5) для п'ятого типу (наглядача, мислителя) - цілі i обов'язки є неточними, лідер непродуктивний, інші вмішуються в роботу, колеги нехтують дедлайнами;

6) для шостого типу (лояліста) - керівництво зловживає посадою, колеги обирають швидкість, а не якість, необхідність приймати рішення самостійно;

7) для сьомого типу (ентузіаста) - колеги заперечують можливість втілення завдання, не підтримують ідеї, зібрання нудні;

8) для восьмого типу (конфронтатора, боса) - колеги обговорюють за спиною, діють нерішуче, не відповідають чітко на запитання, обмежують його дії;

9) для дев'ятого типу (миротворця, посередника) - не розуміють поставлене завдання, думку не враховують, замість прохання віддають накази.

Складається враження, що певні типи природжені керівники, інші - співробітники. Частково так, проте кожен проявляе себе по-особливому, як на управлінських, так і на виконавчих посадах (табл.1).

Особливості впливу еннеатипу на поведінку різних категорій персоналу організації

\begin{tabular}{|c|c|c|c|}
\hline Еннеатипи & $\begin{array}{c}\text { Мотиваційні } \\
\text { фактори }\end{array}$ & Керівники & Співробітники \\
\hline $\begin{array}{l}\text { Перший тип } \\
\text { перфекціоністи }\end{array}$ & $\begin{array}{l}\text { права та } \\
\text { можливості } \\
\text { покращення, } \\
\text { реформування }\end{array}$ & 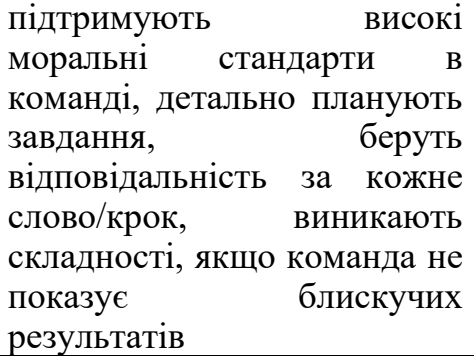 & $\begin{array}{l}\text { дотримуються ієрархії } \\
\text { довіряють та } \\
\text { підводять, здторитетам, не } \\
\text { внутрішнього «критика» на членів } \\
\text { команди, потребують схвалення } \\
\text { керівника, інколи не вкладаються в } \\
\text { дедлайни - робота має бути } \\
\text { ідеальною }\end{array}$ \\
\hline $\begin{array}{l}\text { Другий тип - } \\
\text { помічники }\end{array}$ & $\begin{array}{l}\text { вплив на інших, } \\
\text { допомога колегам }\end{array}$ & $\begin{array}{l}\text { уважні до співробітників та } \\
\text { ix побажань, створюють }\end{array}$ & $\begin{array}{l}\text { важко сприймають критику, } \\
\text { намагаються отримати погодження }\end{array}$ \\
\hline
\end{tabular}


РОЗДІЛ ІІІ. Економіка та управління підприсмствами 2, 2020

\begin{tabular}{|c|c|c|c|}
\hline & & $\begin{array}{l}\text { позитивну атмосферу в } \\
\text { колективі, } \\
\text { співробітників, } \\
\text { некомфортно } \\
\text { роботу інших }\end{array}$ & 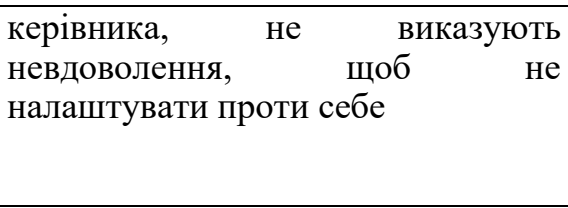 \\
\hline $\begin{array}{l}\text { Третій тип } \\
\text { мотиватори, } \\
\text { досягатори }\end{array}$ & $\begin{array}{l}\text { публічне } \\
\text { визнання } 3 \text { боку } \\
\text { керівництва, } \\
\text { підлеглих }\end{array}$ & $\begin{array}{l}\text { налаштовані на досягнення } \\
\text { цілей, великі очікування до } \\
\text { співробітників, швидкий } \\
\text { підйом за кар'єрною } \\
\text { драбиною, трудоголіки, не } \\
\text { мають часу для відпочинку }\end{array}$ & $\begin{array}{l}\text { при чіткій цілі стрімко йдуть до } \\
\text { успіху, цінують керівника, що } \\
\text { прислуховується до ї ідей, } \\
\text { подавлені, якщо ініціатива не } \\
\text { сприймається }\end{array}$ \\
\hline $\begin{array}{l}\text { Четвертий тип- } \\
\text { індивідуалісти }\end{array}$ & $\begin{array}{l}\text { можливість } \\
\text { внести свій } \\
\text { унікальний, } \\
\text { креативний вклад }\end{array}$ & $\begin{array}{l}\text { самовдосконалюються, } \\
\text { враховують почутя } \\
\text { співробітників, } \text { шукають } \\
\text { проблеми в собі, націлені на } \\
\text { створення у унікального } \\
\text { продукту/послуги. }\end{array}$ & $\begin{array}{l}\text { уникають конфліктів, відкрито } \\
\text { говорять про наявні проблеми, } \\
\text { високий рівень емоціонального } \\
\text { інтелекту, при п підтримці } \\
\text { колективу/керівника } \\
\text { відзначаються } \\
\text { працездатністю }\end{array}$ \\
\hline $\begin{array}{l}\text { П’ятий тип - } \\
\text { наглядачі, } \\
\text { мислителі }\end{array}$ & $\begin{array}{l}\text { нові знання, } \\
\text { можливість } \\
\text { покращити уже } \\
\text { існуюче }\end{array}$ & $\begin{array}{l}\text { вирішують проблеми } \\
\text { раціонально, постійно } \\
\text { аналізують інформацію для } \\
\text { ефективного плану дій, } \\
\text { надійні партнери в бізнесі, } \\
\text { уникають спілкування } \\
\text { колективом, не публічні }\end{array}$ & $\begin{array}{l}\text { фокусуються на роботі, працюють } \\
\text { самостійно, поважають особисті } \\
\text { кордони, надійні при чітких } \\
\text { проєктах та задачах, не люблять } \\
\text { несподіванок }\end{array}$ \\
\hline $\begin{array}{l}\text { Шостий тип - } \\
\text { лоялісти }\end{array}$ & $\begin{array}{l}\text { особистий } \\
\text { простір для } \\
\text { роботи, } \\
\text { можливість } \\
\text { встановлювати } \\
\text { дедлайни }\end{array}$ & $\begin{array}{l}\text { відповідальні, оцінюють та } \\
\text { зважують можливі ризики, } \\
\text { скептично відносяться до } \\
\text { факту влади }\end{array}$ & $\begin{array}{l}\text { задають безліч } \\
\text { продуктивні, потребують довіри зі } \\
\text { сторони колег та керівництва, не } \\
\text { люблять несподіванок }\end{array}$ \\
\hline $\begin{array}{l}\text { Сьомий тип } \\
\text { ентузіасти }\end{array}$ & $\begin{array}{l}\text { необмежені } \\
\text { можливості та } \\
\text { варіанти, «політ } \\
\text { фантазії» }\end{array}$ & $\begin{array}{lr}\text { надихають } & \text { команду, не } \\
\text { вибудовують } & \text { ієрархію на } \\
\text { роботі, не } & \text { витримують } \\
\text { контролю, некомфортно } \\
\text { себе відчувають у ролі } \\
\text { керівника }\end{array}$ & $\begin{array}{l}\text { чутливі до критики, важко } \\
\text { концентруються, гостро реагують } \\
\text { на обмеженості, } \\
\text { налагоджують контакт з колегами, } \\
\text { у роботі надають перевагу свободі } \\
\text { дій }\end{array}$ \\
\hline $\begin{array}{l}\text { Восьмий тип - } \\
\text { конфронтатор } \\
\text { Бос }\end{array}$ & $\begin{array}{l}\text { можливість } \\
\text { користуватися } \\
\text { силою, мати } \\
\text { владу над кимось }\end{array}$ & $\begin{array}{l}\text { надихають співробітників на } \\
\text { вирішення складних } \\
\text { завдань, комфортно себе } \\
\text { відчувають у ролі лідера, } \\
\text { вміють надавати колегам } \\
\text { простір для дій, мають } \\
\text { труднощі } \\
\text { вислуховуванням } \\
\text { співробітників }\end{array}$ & $\begin{array}{l}\text { надають перевагу свободі дій, } \\
\text { цілком вкладаються в справу, } \\
\text { важливо знати, що їх думку } \\
\text { поважають і враховують, інколи } \\
\text { ставлять під сумнів дії керівника }\end{array}$ \\
\hline $\begin{array}{l}\text { Дев’ятий тип } \\
\text { миротворець, } \\
\text { посередник }\end{array}$ & $\begin{array}{l}\text { гармонійна } \\
\text { атмосфера } \\
\text { робочому } \\
\text { колективі }\end{array}$ & $\begin{array}{l}\text { досягнення приписують } \\
\text { команді, розпізнають сильні } \\
\text { сторони в кожному } \\
\text { співробітнику, створюють } \\
\text { розслаблену атмосферу та } \\
\text { легко вирішують конфлікти } \\
\text { між робітниками, вміють } \\
\text { згуртувати різних людей в } \\
\text { єдину команду }\end{array}$ & $\begin{array}{l}\text { легкі у спілкуванні, працьовиті, } \\
\text { ефективні, ставлять чужі потреби } \\
\text { вище своїх, різко висловлюють } \\
\text { свою думку }\end{array}$ \\
\hline
\end{tabular}

Джерело: сформовано авторами на основі $[1-5 ; 8 ; 10-12 ; 14 ; 15]$. 
Висновки та перспективи подальших досліджень. Різні типи управлінських рішень вимагають різних інформаційних даних. Не дивлячись на те, що еннеаграма особистості залишається моделлю невизнаною в академічному середовищі, оскільки не має обгрунтованої наукової бази, вона може стати дієвим інструментом керівника в ухваленні управлінських рішень, що, в свою чергу, підвищить ефективність бізнесу. Цінність еннеаграми полягає перш за все в усвідомленні особливостей інших людей, можливості змінити на краще динаміку конфлікту, адже до кожного типу потрібен особистісний підхід, розкрити потенціал працівника, правильно змотивувати його та вирішувати конфлікти ще на ранніх етапах. Тому, сучасним бізнес-організаціям варто уважніше підійти до можливості використання еннеаграми як інструменту для аналізу та управління комунікативними процесами в конфлікті задля створення сприятливої атмосфери в колективі та підвищення продуктивності праці.

Перспективи подальших досліджень вбачаємо у можливості вивчення впливів еннеатипів на комунікативні процеси в бізнес-структурах, що визначають взаємини та взаємозв'язки їх суб'єктів, i, в свою чергу, дозволять розширити базу дослідження для вироблення оптимальних рішень при складних конфліктно-кризових ситуаціях.

\section{Джерела та література}

1. Наранхо К. 27 персонажей в поисках бытия. Опыт изменения себя в свете эннеаграммы / перевод с испан. Ю. Волковой. Москва: Класс, 2016. 408 с.

2. Pacwa M. Tell Me Who I Am, O Enneagram. Christian Research Journal. URL: https://christian.net/pub/resources/text/cri/cri-jrnl/web/crj0146a.html (дата звернення: 16.05.2020).

3. Макани Х. К. Эннеаграмма: Ваш путь личностного развития. Пер. с англ. И. Каропы. Москва: Ганга, 2012. $288 \mathrm{c}$.

4. Тэллон Р, Сикора М. Осознанность в действии. Эннеаграмма, коучинг и развитие эмоционального интеллекта. Пер. с англ. М. Калдина. Москва: Ориенталия, 2017. 432 с.

5. Kingma L. What's Your Tribe?: An Enneagram Guide to Human Types at Work and Play. Lansdowne : Juta and Company Ltd, 2009. 115 p.

6. Newgent R.A., Parr P.E., Higgins K.K. The Riso-Hudson Enneagram Type Indicator: Estimates of reliability and validity. Measurement and evaluation in counseling and development. 2004. Vol. 36. P. 226-237.

7. Kilmann R. H. A Brief History of the Thomas-Kilmann Conflict Mode Instrument (TKI). URL: https://kilmanndiagnostics.com/a-brief-history-of-the-thomas-kilmann-conflict-mode-instrument/ дата звернення: 15.04.2020).

8. Протасова А. Введення в в еннеаграму: вебінар. URL: https://ennearesourse.ru/pl/teach/control/lesson/view?id=115219056\&editMode=0 (дата звернення: 14.05 .2020 ).

9. Бандурка А. М., Бочарова С. П., Землянская Е. В. Психология управления : учебник. Харьков: Фортуна-пресс, 1998. 464 с.

10. Рисо Д. Р., Хадсон Р. Мудрость Эннеаграммы. Полное руководство по психологическому и духовному росту для девяти типов личности. Москва : Открытый Мир, 2016. 536 с.

11. Бергхоф К., Бэлл М. Эннеаграмма для современной жизни. Узнай, кто ты и кем можешь стать. Пер. с англ. Е. Никитиной. Москва : Эксмо, 2020. 256 с.

12. Адизес И., Маданес И. От застоя к росту. Как раскрыть и развить в себе потенциал бизнес-лидера: бизнес-книга. Пер. А .В. Чедия. Москва : Манн, Иванов и Фербер, 2015. 144 с.

13. Арзуманов Р.М. Менеджмент предпринимательской деятельности: управление развитием бизнеса : учеб. пособ. Феодосия: Гнозис, 2014. 226 с.

14. Панграцці А. Подорож всередину себе. Еннеаграма як теорія особистості / пер. О. Якимець. Львів : Колесо, 2011. $176 \mathrm{c}$.

15. The Enneagram in Business. Conflict. URL: https://theenneagraminbusiness.com/businessapplications/conflict/ (дата звернення: 05.04.2020).

\section{References}

1. Naranho, K. (2016). 27 personazhey v poiskah byitiya. Opyit izmeneniya sebya $v$ svete enneagrammyi. [27 characters in search of being. The experience of changing oneself in the light of the enneagram]. (Yu. Volkovoy, Trans.). Moskva: Klass [in Russian].

2. Pacwa, M. (1994). Tell Me Who I Am, O Enneagram. Christian Research Journal. Retrieved from https://christian.net/pub/resources/text/cri/cri-jrnl/web/crj0146a.html [in English]. 
3. Makani, H. K. (2012). Enneagramma: Vash put lichnostnogo razvitiya. [Enneagram: Your personal development path]. (I. Karopyi, Trans.). Moskva: Ganga [in Russian].

4. Tellon, R. \& Sikora, M. (2017) Osoznannost v deystvii. Enneagramma, kouching i razvitie emotsionalnogo intellekta. [Awareness in action. Enneagram, coaching and development of emotional intelligence]. (M. Kaldina, Trans.). Moskva: Orientaliya [in Russian].

5. Kingma, L. (2009). What's Your Tribe?: An Enneagram Guide to Human Types at Work and Play. Lansdowne : Juta and Company Ltd [in English].

6. Newgent, R. A., Parr, P. E. \& Higgins, K. K. (2004). The Riso-Hudson Enneagram Type Indicator: Estimates of reliability and validity. Measurement and evaluation in counseling and development. (Vols. 36), (pp.226237) [in English].

7. Kilmann, R. H. (n.d.). A Brief History of the Thomas-Kilmann Conflict Mode Instrument (TKI). Retrieved from https://kilmanndiagnostics.com/a-brief-history-of-the-thomas-kilmann-conflict-mode-instrument/ [in English].

8. Protasova, A. (n.d.). Vvedennya v enneagramu: vebinar [Introduction to the enneagram: webinar]. Retrieved from https://ennearesourse.ru/pl/teach/control/lesson/view?id=115219056\&editMode=0

9. Bandurka, A. M., Bocharova, S. P. \& Zemljanskaja, E. V. (1998). Psykhologhyja upravlenyja [Management psychology]. Kharkov: Fortuna-press [in Ukrainian].

10. Riso, D. R. \& Hadson, R. (2016) Mudrost Enneagrammyi. Polnoe rukovodstvo po psihologicheskomu $i$ duhovnomu rostu dlya devyati tipov lichnosti [The Wisdom of the Enneagram. A complete guide to psychological and spiritual growth for nine personality types]. Moskva : Otkryityiy Mir [in Russian].

11. Berghof, K. \& Bell, M. (2020). Enneagramma dlya sovremennoy zhizni. Uznay, kto tyi i kem mozhesh stat [Enneagram for modern life. Find out who you are and who you can become]. (E. Nikitinoy, Trans.). Moskva : Eksmo [in Russian].

12. Adizes, I. \& Madanes, I. (2015). Ot zastoja k rostu. Kak raskryit i razvit v sebe potentsial biznes-lidera [From stagnation to growth. How to unleash and develop the potential of a business leader]. (A .V. Chediya, Trans.). Moskva: Mann [in Russian].

13. Arzumanov, R. M. (2014). Menedzhment predprynymateljskoj dejateljnosty: upravlenye razvytyem byznesa [Entrepreneurship Management: Business Development Management]. Feodosiya: Gnozis [in Ukrainian].

14. Pangracci, A. (2011). Podorozh vseredynu sebe. Enneaghrama jak teorija osobystosti [Journey inside yourself. Enneagram as a theory of personality]. Lviv: Koleso [in Ukrainian].

15. The Enneagram in Business. Conflict. (n.d.). theenneagraminbusiness.com. Retrieved from https://theenneagraminbusiness.com/business-applications/ conflict/ [in English].

Стаття надійшла до редакції 19.05.2020 p. 